\title{
СОВРЕМЕННЫЕ МОДЕЛИ КОНСТИТУЦИОННО-ПРАВОВОГО РЕГУЛИРОВАНИЯ ПРАВА ЧЕЛОВЕКА НА РАЗВИТИЕ
}

\begin{abstract}
Аннотация: Статья посвящена анализу конституционно-правового регулирования права человека на развитие в различных государствах мира. На основании исследования значительного числа конституционных норм автор выявляет содержание и особенности права человека на развитие, специфику конституционно-правового закрепления данного права. В статье исследуются конституционные нормы, посвященные развитию как всестороннему экономическому, социальному, культурному и политическому процессу, правам человека, участию в развитии и в справедливом распределении создаваемых в ходе его благ, равенству возможностей, повышению благосостояния населения и другим элементам содержания права человека на развитие. С использованием универсального, сравнительно-правового, формально-юридического методов автором исследуются конституционные нормы, закрепляющие право человека на развитие. Автор приходит к выводу о существовании двух моделей конституционно-правового регулирования права человека на развитие: прямого и опосредованного его закрепления в нормах конституции. Несмотря на то, что прямое закрепление права человека на развитие в текстах конституций является оптимальным способом обеспечения его реализации, дальнейтее развитие конституичонно-правового регулирования права на развитие по пути расширения числа закрепленных в конституциях отдельных элементов содержания права на развитие может быть не менее эффективным.
\end{abstract}

Ключевые слова: Право на развитие, права человека, развитие, равенство возможностей, конституция, соцчиальная справедливость, экономическое развитие, устойчивое развитие, справедливое распределение благ, правовое регулирование .

Abstract: This article is dedicated to the analysis of the constitutional law regulation of the human right to development in various countries of the world. Based on the research of a significant number of constitutional norms, the author determines the content and peculiarities of the human right to development, as well as the specificity of the constitutional law provisions on this right. The author examines constitutional norms dedicated to development as comprehensive economic, social, cultural, and political process, human rights, participation in development and fair distribution of its benefits, equality of opportunity, increase of wealth of the population, and other elements of support of the human right to development. The author concludes that there are two models of constitutional law regulations of the human right to development: direct, and that mediated in the norms of the Constitution. Despite the fact that direct support of the human right to development in the texts of the Constitutions is an optimal way of ensuring its realization, further development of the constitutional law regulation of the right to development via expansion of the number of separate constitutional elements supporting the right to development can be just as effective.

Keywords: Economic development, social justice, constitution, equal opportunity, development, Human rights, Right to development, sustainable development, fair distribution of benefits, legal regulation.

онцепция права на развитие возникла в 1970-е гг. [65, Р. 528-530]. В 1986 г. основные элементы содержания права на развитие получили закрепление в Декларации ООН о праве на развитие [1], которая выступает в настоящее время основным документом, определяющим содержание права на развитие, хотя и не носит обязательного характера.

Декларация о праве на развитие в части 1 статьи 1 определяет право на развитие как неотъемлемое право человека, в силу которого каждый человек и все народы имеют право участвовать в таком экономическом, социальном, культурном и политическом развитии, при котором могут быть полностью осу- ществлены все права человека и основные свободы, а также содействовать ему и пользоваться его благами. В преамбуле Декларации о праве на развитие поясняется, что «развитие является всесторонним экономическим, социальным, культурным и политическим процессом, направленным на постоянное повышение благосостояния всего населения и всех лиц на основе их активного, свободного и конструктивного участия в развитии и в справедливом распределении создаваемых в ходе его благ».

Анализ текста Декларации о праве на развитие позволяет выделить следующие элементы содержания права на развитие: во-первых, объектом права на 
развитие является развитие, понимаемое как всесторонний экономический, социальный, культурный и политический процесс; во-вторых, этот процесс должен быть направлен на повышение благосостояния всего населения и всех лиц на основе их активного, свободного и конструктивного участия в развитии и в справедливом распределении создаваемых в ходе его благ. Статья 8 Декларации о праве на развитие конкретизирует, что этот процесс должен характеризоваться равенством возможностей для всех в том, что касается доступа к основным ресурсам, образованию, здравоохранению, питанию, жилью, занятости и справедливому распределению доходов, а также способствовать ликвидации любой социальной несправедливости; в-третьих, его результатом должно быть полное осуществление всех прав человека и основных свобод.

В дальнейшем международно-правовое регулирование права на развитие было дополнено и подкреплено положениями целого ряда резолюций Генеральной Ассамблеи ООН. Кроме того, право на развитие впервые нашло закрепление в международном акте обязательного характера в качестве самостоятельного и общепризнанного права человека - в Парижском соглашении к Рамочной конвенции ООН об изменении климата 2015 г. [2] Однако универсальный обязательный международный акт специального характера по праву на развитие по-прежнему отсутствует.

Правовое регулирование права на развитие не исчерпывается международным уровнем, и закрепление его государствами мира в национальном праве, и, прежде всего - на конституционном уровне, имеет не менее важное значение. Между тем, в настоящее время отсутствуют исследования конституционных норм по праву на развитие, комплексно раскрывающие его содержание и особенности, а имеющиеся работы носят теоретический $[48 ; 56 ; 61 ; 66]$ или международно-правовой характер $[46 ; 47 ; 50 ; 52 ; 53$; 55; 57; 62; 63; 64], либо посвящены отдельным, очень узким, конституционным аспектам права на развитие [49; 54; 59; 60].

Можно выделить две модели конституционноправового регулирования права человека на развитие:

1) прямое закрепление права на развитие на конституционном уровне;

2) непрямое (опосредованное) закрепление права на развитие.

Безусловно, практически в каждой конституции встречаются положения, касающиеся развития во всем многообразии проявлений этого процесса. Однако прямое закрепление права на развитие на конституционном уровне в настоящее время не просто минимально, а являет собой исключительные случаи. Так, право на развитие прямо закреплено только в конституциях Эфиопии, Малави, Уганды и Португалии.

Право на развитие закреплено в Конституции Эфиопии от 8 декабря 1994 года [42] в положениях статьи 43. Согласно части 1 статьи 43 народу Эфиопии вообще и нациям, национальностям и народностям Эфиопии в частности гарантируется право на улучшение уровня жизни и устойчивое развитие. Согласно части 2 статьи 43 граждане имеют право принимать участие в национальном развитии и, в частности, требовать учета их мнения при определении политики и проектов, затрагивающие интересы общности, к которой они принадлежат.

Часть 1 статьи 43 может рассматриваться двояко: как комплексная норма, закрепившая обобщенно право на развитие с акцентом на устойчивость развития и рост благосостояния, либо как норма, закрепившая два права с самостоятельным содержанием - право на устойчивое развитие и право на улучшение уровня жизни. Первый вариант, представляется, более точно отражает содержание данной нормы, а положения части 2 статьи 43, закрепляя право на участие в развитии, подтверждают такое предположение. Таким образом, в совокупности данные нормы могут рассматриваться именно как закрепляющие право человека на развитие.

Рассмотренные положения также дополняются другими нормами Конституции Эфиопии. Прежде всего, речь идет о статье 89 , согласно части 5 которой государство должно обеспечивать участие населения на всех этапах подготовки политики и программ развития страны и поддерживать инициативы населения в области развития. Часть 6 статьи 89 предусматривает обязанность государств способствовать участию женщин наравне с мужчинами в экономическом и социальном развитии. Данное положение дополняется положением части 6 статьи 35 (посвященной правам женщин) Конституции Эфиопии, согласно которому женщины имеют право требовать, чтобы учитывалось их мнение по вопросам национальной политики развития.

Конституция Республики Уганда от 8 октября 1995 года [29] закрепляет право на развитие в общих положениях раздела «Национальные цели и руководящие принципы государственной политики». При этом право на развитие не формулируется в стандарте права человека или народов на развитие, а раскрывается через набор свойственных ему признаков. Так, статья IX «Право на развитие» гласит, что с целью содействовать быстрому и справедливому развитию, государство должно поощрять частную инициативу 
и самостоятельность. Согласно статье X «Роль народа в развитии» государство должно принимать все необходимые шаги, чтобы вовлекать народ в разработку и реализацию планов и программ развития, которые их касаются. Статья XI «Роль государства в развитии» предусматривает, что государство должно отдавать самый высокий приоритет изданию нормативных актов, устанавливающих меры для защиты и усиления права народа на равные возможности в развитии; государство должно стимулировать сельскохозяйственное, промышленное, технологическое и научное развитие путем утверждения соответствующей политики и издания необходимых нормативных актов; для обеспечения социальной справедливости государство может регулировать приобретение, владение, использование и распоряжение землей и другой собственностью в соответствии с Конституцией.

Согласно части 1 статьи 30 Конституции Малави от 16 мая 1994 года [16] каждый человек и все народы имеют право на развитие, в силу которого могут пользоваться благами экономического, социального, культурного и политического развития; осуществлению этого права женщинами, детьми и инвалидами должно уделяться особое внимание. Части 2-4 статьи 30 посвящены обязанностям государства, вытекающим из права на развитие. Так, государство должно принимать все необходимые меры для реализации права на развитие. Такие меры среди прочих должны включать равенство возможностей для всех в доступе к основным ресурсам, образованию, здравоохранению, еде, жилищу, занятости и инфраструктуре. Государство должно принимать меры к проведению реформ, направленных на искоренение социальной несправедливости и неравенства. Государство несет обязанность уважать право на развитие и проводить политику в соответствии с этой обязанностью.

Таким образом, Конституция Малави наиболее полно закрепляет содержание права человека на развитие, в частности, такие элементы как пользование благами развития, равенство возможностей в доступе к ресурсам, необходимым для развития. Особое внимание уделено субъектному составу права на развитие: оно формулируется не только как одновременно индивидуальное и коллективное право, но и делается акцент на его значении для наименее защищенных субъектов. Кроме того, Конституция Малави непосредственно предусматривает ряд обязанностей государства, вытекающих из права на развитие. Тем самым, на сегодняшний день Конституция Малави может служить образцом конституционно-правового закрепления права человека на развитие на национальном уровне.
Чтобы подчеркнуть специфику Африканского региона, здесь целесообразно рассмотреть также положения Конституции Мадагаскара от 19 августа 1992 года [15]. Она не упоминает прямо в тексте право на развитие, однако в преамбуле провозглашается приверженность страны Африканской хартии прав человека и народов. То есть фактически Конституция Мадагаскара содержит отсылку к Африканской хартии прав человека и народов от 26 июня 1981 года $[58$, с. 70], которая является региональным международным документом обязательного характера, закрепившим право на развитие. В преамбуле Африканской хартии говорится, что существенно важно уделять особое внимание обеспечению права на развитие. Согласно статье 22 Африканской хартии все народы имеют право на собственное экономическое, социальное и культурное развитие с должным учетом своей свободы и самобытности и при равноправном доступе к общему наследию человечества. Государства обязаны индивидуально или коллективно обеспечивать право на развитие.

Кроме того, в преамбуле Малагасийской конституции признаются следующие основные условия для гармоничного развития: рациональное и справедливое руководство природными ресурсами для нужд развития человека; уважение и защита основных свобод, как личных, так и коллективных; защита национального единства при претворении в жизнь политики сбалансированного развития во всех сферах. Также в статье 26 закреплен общий принцип участия в развитии применительно к конкретным сферам: каждый человек имеет право принимать участие в культурной жизни общества, в научном прогрессе и пользоваться их благами.

Конституция Португальской Республики от 2 апреля 1976 года [18] заслуживает, пожалуй, особого внимания, поскольку, помимо права народов на развитие, закрепила значительное число принципов, которые в контексте права на развитие составляют его содержание, как-то: равенство возможностей, участие, справедливое распределение доходов, рост благосостояния.

Согласно части 3 статьи 7 Конституции Португальской Республики Португалия признает право народов на самоопределение и независимость и на развитие. В части 2 статьи 73, посвященной праву на образование и пользование достижениями культуры, говорится, что государство способствует демократизации системы образования с тем, чтобы образование вносило вклад в выравнивание возможностей, в преодоление экономического, социального и культурного неравенства, в развитие личности и 
духа терпимости, взаимопонимания, солидарности и ответственности, в демократическое участие в общественной жизни и в социальный прогресс. В статье 81 Конституции Португалии среди первоочередных обязанностей государства в экономической и социальной сферах называется обязанность государства способствовать росту социального и экономического благосостояния и качества жизни людей, особенно наименее обеспеченных (пункт «а»). Согласно статье 90 планы экономического и социального развития должны быть нацелены на стимулирование экономического роста, сбалансированного развития секторов и областей, справедливого распределения национального продукта между индивидами и между регионами, координации экономической политики с социальной политикой и политикой в области образования и культуры, сохранения экологического равновесия, охраны окружающей среды и качества жизни португальского народа.

Конституции, прямо закрепившие право на развитие, позволяют отметить следующую явную тенденцию: поддержку на национальном уровне получил коллективный аспект права на развитие - право на развитие как право народов. Представляется, что данное обстоятельство связано с тем, что право на развитие начало формироваться как право государств в международном праве, а затем - как право народов. Индивидуальный же аспект - право на развитие как право человека - появился несколько позже, тем самым государства оказались более подготовлены к восприятию коллективного аспекта, чем индивидуального.

Минимальность прямого закрепления права на развитие в конституциях стран мира в некоторой степени компенсируется наличием в целом ряде конституций положений, соответствующих различным элементам содержания данного права. Это могут быть отдельные характеристики развития, свойственные ему как объекту права человека, связанное с развитием равенство возможностей, социальная справедливость, справедливое распределение национального дохода, равноправие, провозглашение целью развития реализацию всех прав человека, право населения участвовать в развитии, принципы устойчивого развития. Кроме того, некоторые конституции устанавливают обязанность государства способствовать развитию.

Такая форма является опосредованным закреплением права на развитие. При этом следует учитывать, что такие элементы, как правило, не закреплены в тексте одной конституции в достаточном комплексе, чтобы в полной мере отражать содержание права на развитие. Однако в любом случае подобные нормы конституций заслуживают внимания, поскольку они позволяют оценить все многообразие элементов, составляющих содержание права на развитие, а также конституционно-правовой контекст их употребления.

В конституциях государств мира находит отражение все многообразие общественных отношений, которые охватывает процесс развитие. В самом общем виде речь идет о всеобъемлющем [35], всеобщем и всестороннем [8; 11] развитии страны [18], государства [28; 14], общества [41], национальном развитии $[42 ; 30 ; 32]$.

В конституциях государств мира широко представлены составляющие процесса развития: экономическое (развитие экономики) $[10 ; 44 ; 7 ; 31 ; 33 ; 17 ; 23 ; 35$; $34 ; 3 ; 37]$, социальное $[17 ; 13 ; 18 ; 25 ; 21 ; 30 ; 37 ; 10 ; 42 ; 17$; 8], политическое [21], культурное (развитие культуры) $[12 ; 25 ; 20 ; 7 ; 6 ; 27 ; 3 ; 45 ; 26 ; 35]$, экологическое [32] развитие. Следует отметить при этом, что взаимосвязь и взаимозависимость компонентов процесса развития находит отражение и в конституциях, где они зачастую формулируются именно в комплексе $[17 ; 14 ; 21$; $32 ; 37 ; 39]$. Особенно тесная связь отмечается между экономической и социальной составляющими развития, которые и терминологически в конституциях часто связаны между собой (социально-экономическое развитие) $[35 ; 6 ; 18 ; 28 ; 39]$.

Экономическое развитие включает в себя развитие территорий (территориальное развитие) [23; 18; 25], в том числе развитие национальной территории [18], региональное развитие (районов страны) [32; 17; $20 ; 30 ; 25 ; 22]$, развитие городов $[17 ; 10]$ и сельской местности (сельской округи) [10; 18], аграрное (сельскохозяйственное) развитие $[30 ; 37 ; 18]$, развитие национального (общественного) благосостояния [30; 43], развитие негосударственного сектора экономики [10] (кооперации [21; 7], предпринимательства, малого и среднего бизнеса [37]), промышленности[37; 18] и торговли [18], всех форм собственности [21], технологическое развитие (развитие технологий) [25; 35], развитие науки (научно-техническое развитие) [39; 20;36; $35 ; 25 ; 31 ; 3 ; 22 ; 25 ; 39 ; 14]$ и (научных и технических) исследований [12; 21; 7], развитие туризма [12; 28; 22].

Социальное развитие предполагает развитие здравоохранения (лечебных учреждений) [3; $14 ; 32$; 39], развитие физической культуры и спорта [21; 39; $31 ; 35 ; 18 ; 14 ; 20 ; 27 ; 32 ; 28]$, досуга и отдыха $[13 ; 12]$, восстановительных мероприятий [19].

Культурное развитие включает развитие искусства $[42 ; 25 ; 31 ; 3 ; 22]$, литературы, прессы, теле- и радиовещания, библиотек, музеев, культурных центров [10], народного творчества [38], ремесел [7; 36], развитие сети культурно-просветительных уч- 
реждений [21], развитие образования [20;35; 3; 22] и учебных заведений [14], развитие национальной идентичности [25], этнической, культурной, языковой и религиозной самобытности [26; 33], развитие (родного) языка $[39 ; 27 ; 32]$ или языков всех народов и общностей $[14 ; 23 ; 12]$.

Экологическое развитие предполагает развитие среды обитания [41] и естественных (природных) ресурсов [24], в том числе развитие заповедников и естественных парков, парков отдыха [18], а также устойчивое развитие $[27 ; 19 ; 45]$.

Следует помнить, что в конституциях находят отражение далеко не все аспекты процесса развития, а только те, которые каждое конкретное государство полагает конституционно значимыми для своих реалий. Поэтому не следует полагать, что процесс развития исчерпывается указанными выше элементами.

Особого внимания заслуживает отражение в национальных конституциях одного из основных признаков развития как объекта права человека - его целью выступает наиболее полная реализации прав человека. Данный элемент косвенно закреплен в Конституции Кооперативной Республики Гайана 1980 года [11]. Она называет реализацию прав человека целью экономического развития страны. Согласно пункту 38 Главы II Конституции Гайаны обязанностью государства, кооперативов, профсоюзов и других социально-экономических организаций и людей является достижение через постоянные и организованные усилия максимально возможных уровней производства и производительности и развитие экономики с целью гарантировать реализацию прав человека, изложенных в Главе II. Согласно статье 21 Конституции Республики Беларусь [21] от 15 марта 1994 года обеспечение прав и свобод граждан Республики Беларусь является высшей целью государства.

Пожалуй, наибольшее признание на конституционном уровне получил принцип участия населения и каждого человека в развитии. Как подтверждение приверженности принципу участия в развитии следует рассматривать не только прямое указание на это, но также обобщенные формулировки, как-то, «участие в жизни общества» и тому подобные, а также указания на важность участия в развитии конкретных субъектов.

Выше уже были приведены нормы, касающиеся участия в развитии, содержащиеся в конституциях Эфиопии, Мадагаскара и Португалии. Отметим также конституции Испании и Беларуси, закрепивших положения, касающиеся участия граждан в жизни общества и участия молодежи в развитии.

Согласно части 2 статьи 9 Конституции Королевства Испания от 27 декабря 1978 года [12] публичные власти обеспечивают условия, при которых свобода и равенство становятся действительными и эффективными, а также устраняют все препятствия на пути полного развития индивидов и их групп и способствуют участию всех граждан в политической, экономической, культурной и социальной жизни. Согласно статье 48 публичные власти способствуют созданию необходимых условий для свободного и эффективного участия молодежи в политическом, социальном, экономическом и культурном развитии. Согласно статье 32 Конституции Республики Беларусь от 15 марта 1994 года [21] государство создает необходимые условия для свободного и эффективного участия молодежи в политическом, социальном, экономическом и культурном развитии. Параграф 2 Конституции Финляндии от 11 июня 1999 года [41] закрепляет право личности на участие в развитии общества и своего жизненного окружения, оказание влияния на такое развитие, как элемент народовластия.

Не меньше внимания, чем принцип участия в развитии, заслуживает закрепление в конституциях применительно к процессу развития принципа социальной справедливости и связанных с ним принципов равенства возможностей и справедливого распределения благ развития.

Конституция Филиппин 1987 года [30] в статье 2 , посвященной государственной политике, предусматривает, что государство должно обеспечивать социальную справедливость на всех ступенях национального развития (раздел 10). Также отметим положение раздела 17 статьи 2, согласно которому государство должно отдавать приоритет образованию, науке и технологии, искусству, культуре и спорту с целью ускорить социальный прогресс и обеспечить всеобщую свободу и развитие человека.

Зачастую социальная справедливость называется в конституциях в одном ряду с ростом благосостояния человека (народа). Согласно статье 20 Конституции Государства Кувейт, принятой 11 ноября 1962 года, [5] национальная экономика должна основываться на социальной справедливости, при этом ее целью является экономическое развитие, рост производительности, улучшение уровня жизни и достижение благосостояния граждан. В преамбуле Конституции Кыргызской Республики от 27 июня 2010 года [14] провозглашается, что народ Кыргызстана принимает Конституцию, в том числе стремясь обеспечить социальную справедливость, экономическое благосостояние и духовное развитие народа.

Отметим сразу положения конституций, призванные закрепить необходимость обеспечения роста 
благосостояния народа. Согласно статьям 15 и 16 Конституции Азербайджанской Республики от 12 ноября 1995 года [3], посвященным экономическому и социальному развитию государства, Азербайджанское государство заботится о повышении благосостояния народа и каждого гражданина и его достойном уровне жизни, чему служит развитие экономики страны. Согласно статье 24 Конституции Японии от 3 ноября 1946 года [43] во всех сферах жизни государство должно прилагать усилия для подъема и дальнейшего развития общественного благосостояния, социального обеспечения, а также народного здравия. Положение общего характера о благе народа в контексте развития также содержится в части 2 статьи 1 Конституции Республики Казахстан от 30 августа 1995 года [23], которая среди основополагающих принципов деятельности Республики называет экономическое развитие на благо всего народа.

Принцип равенства возможностей нашел отражение в Конституции Канады от 17 апреля 1982 года [9], которая непосредственно связала экономическое развитие с равенством возможностей для стремления к благополучию. Согласно пунктам 36 (1) «а», «b» Парламент и законодательные собрания, а также Правительство Канады и правительства провинций обязуются содействовать обеспечению равенства возможностей для всех канадцев в их стремлении к благополучию, а также содействовать экономическому развитию, с тем, чтобы сократить неравенство возможностей.

Принцип справедливого распределения благ развития опосредованно - как справедливое распределение национального дохода и богатства закреплен в Конституции Испании 1978 года. Согласно части 1 статьи 131 Конституции Испании государство посредством издания закона может планировать общую экономическую деятельность в целях удовлетворения коллективных потребностей, выравнивания и гармонизации регионального и секторального развития и стимулирования роста доходов и богатства, а также их наиболее справедливого распределения.

Еще один важный аспект - обязанность государств содействовать развитию своего народа-также нашла отражение в конституционных нормах. Так, Конституция Нидерландов прямо закрепляет данную обязанность, а Конституция Хорватии декларирует общее положение о том, что государство способствует развитию. Конституция Королевства Нидерландов от 17 февраля 1983 года [13] в статье 22 закрепляет обязанность государственных органов содействовать социальному и культурному развитию общества (часть 3), а также связанные с этим обязанности принимать меры по защите здоровья населения (часть 1) и заботиться об обеспечении населению достаточного жизненного уровня (часть 2). Согласно статье 49 Конституции Республики Хорватия от 22 декабря 1990 года [31] государство способствует экономическому прогрессу и социальному благосостоянию граждан и осуществляет заботу об экономическом развитии всех своих территорий.

Невозможно не отметить еще один признак развития как объекта права человека, который также нашел отражение в конституциях стран мира, - экологическая устойчивость развития.

Согласно части 2 статьи 2 Союзной конституции Швейцарской Конфедерации от 18 апреля 1999 года [45] Швейцарская Конфедерация способствует совместному благосостоянию, устойчивому развитию, внутренней сплоченности и культурному многообразию страны. Согласно Конституции Республики Албания от 21 октября 1998 года (часть 1(f) статьи 59) [19] и Конституции Республики Польша от 2 апреля 1997 года (статья 5) [27] указанные государства руководствуются в своей политике принципом устойчивого развития. В Конституции Венгрии от 25 апреля 2011 года (статья Q(1) [4] говорится, что Венгрия должна стремиться к сотрудничеству с другими странами для достижения устойчивого развития человечества.

Таким образом, число государств, прямо закрепивших в своих конституциях право на развитие, все еще остается минимальным. В то же время отдельные элементы, составляющие содержание права на развитие, как-то: равенство возможностей, социальная справедливость, справедливое распределение благ развития, - прочно вошли в конституционную практику различных государств мира.

В конституционном регулировании права на развитие очевидна явная тенденция - право на развитие нашло закрепление в конституциях, принятие которых пришлось на период активных дискуссий вокруг данного права, т.е. в конституциях второго (1970-е гг.) и третьего (1990-е гг.) поколений. В современных же конституциях, принимавшихся с конца 1990-х гг. право на развитие не находит отражения, несмотря на то, что оно получило широкое признание на международном уровне и поддержку со стороны многих государств. Несмотря на то, что прямое закрепление права человека на развитие в текстах конституций является оптимальным способом обеспечения его реализации, представляется, что дальнейшее развитие конституционно-правового регулирования права на развитие должно продолжаться как по пути его непосредственного закрепления, так и по пути расширения в конституциях числа отдельных элементов содержания права на развитие. 
1. Декларация о праве на развитие 1986 года. Принята резолюцией 41/128 Генеральной Ассамблеи ООН от 4 декабря 1986 года. Док. ООН A/RES/41/128. // Система официальной документации ООН [Электронный ресурc]: URL: http:// www.un.org/ru/documents/ (дата обращения: 15.08.2016).

2. Парижское соглашение об изменении климата - итоговой документ 21-й Конференции сторон Рамочной конвенции Организации Объединенных Наций об изменении климата (РКООНИК) 2015 года // Система официальной документации ООН [Электронный ресурc]: URL: http://www.un.org/ru/documents/ (дата обращения: 15.08.2016).

3. Конституция Азербайджанской Республики 1995 года [Электронный pecypc]. URL: http://www.azerbaijan.az/portal/ General/Constitution/constitution_r.html (дата обращения: 15.08.2016).

4. Конституция Венгрии 2011 года [Электронный ресурс]. URL: http://hunconcourt.hu/rules/fundamental-law (дата обращения: 24.08.2016).

5. Конституция Государства Кувейт 1962 года // Конституции стран мира [Электронный ресурc]. URL: http://www. concourt.am/armenian/legal_resources/world_constitutions/constit/kuweit/kuweit-e.htm (дата обращения: 15.08.2016).

6. Конституция Грузии 1995 г. // Законодательный вестник Грузии [Электронный ресурc]. URL: https://matsne.gov.ge/ru/ document/view/30346 (дата обращения: 15.08.2016).

7. Конституция Итальянской Республики 1947 года // Конституции стран мира [Электронный pecypc]. URL: http:// www.concourt.am/armenian/legal_resources/world_constitutions/constit/italy/italy--r.htm (дата обращения: 15.08.2016).

8. Конституция Йемена 1991 года // Конституции стран мира [Электронный ресуpc]. URL: http://www.codices.coe.int/NXT/ gateway.dll/CODICES/constitutions/eng/asi/yem?fn=document-frameset.htm\$f=templates\$3.0 (дата обращения: 15.08.2016).

9. Конституция Канады 1982 года // Конституции стран мира [Электронный ресурc]. URL: http://www.concourt.am/ armenian/legal_resources/world_constitutions/constit/canada/canada-r.htm (дата обращения: 15.08.2016).

10. Конституция Китайской Народной Республики 1982 года // Конституции стран мира [Электронный pecypc]. URL: http:// www.concourt.am/armenian/legal_resources/world_constitutions/constit/china/china--r.htm (дата обращения: 15.08.2016).

11. Конституция Кооперативной Республики Гайана 1980 года // Конституции стран мира [Электронный pecypc]. URL: http://www.concourt.am/armenian/legal_resources/world_constitutions/constit/guyana/guyana-e.htm (дата обращения: 15.08.2016).

12. Конституция Королевства Испания 1978 года // Конституции стран мира [Электронный pecypc]. URL: http://www. concourt.am/armenian/legal_resources/world_constitutions/constit/spain/spain--r.htm (дата обращения: 15.08.2016).

13. Конституция Королевства Нидерландов 1983 года // Конституции стран мира [Электронный ресypc]. URL: http://www. concourt.am/armenian/legal_resources/world_constitutions/constit/nethrlnd/holand-r.htm (дата обращения: 15.08.2016).

14. Конституция Кыргызской Республики 2010 года [Электронный pecypc]. URL: http://www.kyrgyz-el.kg/index. php?option=com_content\&task=view\&id=120\&Itemid=43 (дата обращения: 15.08.2016).

15. Конституция Мадагаскара 1992 года // Конституции стран мира [Электронный ресурc]. URL: http://www.concourt.am/ armenian/legal_resources/world_constitutions/constit/madagas/madgas-e.htm (дата обращения: 15.08.2016).

16. Конституция Малави 1994 года // Конституции стран мира [Электронный ресурc]. URL: http://www.uznal.org/ constitution.php?text=Malawi\&language=e (дата обращения: 15.08.2016).

17. Конституция Монголии 1992 года // Конституции стран мира [Электронный ресуpc]. URL: http://www.concourt.am/ armenian/legal_resources/world_constitutions/constit/mongolia/mongol-e.htm (дата обращения: 15.08.2016).

18. Конституция Португальской Республики 1976 года [Электронный ресурc]. URL: http://www.tribunalconstitucional.pt/ tc/conteudo/files/constituicaoingles.pdf (дата обращения: 15.08.2016).

19. Конституция Республики Албания 1998 года // Конституции стран мира [Электронный pecypc]. URL: http://www. concourt.am/armenian/legal_resources/world_constitutions/constit/albania/albani-r.htm (дата обращения: 15.08.2016).

20. Конституция Республики Армения 1995 года // Конституции стран мира [Электронный ресуpc]. URL: http://www. concourt.am/armenian/legal_resources/world_constitutions/constit/armenia/armeni-r.htm (дата обращения: 15.08.2016).

21. Конституция Республики Беларусь 1994 года [Электронный pecypc]. URL: http://www.president.gov.by/press10669.html (дата обращения: 15.08.2016).

22. Конституция Республики Болгарии 1991 года // Конституции стран мира [Электронный pecypc]. URL: http://www. concourt.am/armenian/legal_resources/world_constitutions/constit/bulgaria/bulgar-r.htm (дата обращения: 15.08.2016).

23. Конституция Республики Казахстан 1995 года [Электронный ресурc]. URL: http://www.akorda.kz/ru/official_documents/ constitution (дата обращения: 15.08.2016).

24. Конституция Республики Корея (Южная Корея) 1948 года [Электронный ресурс]. URL: http://legalportal.am/download/ constitutions/119_ru.pdf (дата обращения: 24.08.2016).

25. Конституция Республики Македония 1991 года // Конституции стран мира [Электронный pecypc]. URL: http://www. concourt.am/armenian/legal_resources/world_constitutions/constit/macedon/macedon-r.htm (дата обращения: 15.08.2016).

26. Конституция Республики Молдова 1994 года [Электронный ресурс]. URL: http://lex.justice.md/viewdoc.php?action=v iew\&view=doc\&id=311496\&lang=2 (дата обращения: 24.08.2016).

27. Конституция Республики Польша 1997 года // Конституции стран мира [Электронный pecypc]. URL: http://www. concourt.am/armenian/legal_resources/world_constitutions/constit/poland/poland-r.htm (дата обращения: 15.08.2016).

28. Конституция Республики Таджикистан 1994 года // WIPO Lex [Электронный pecypc]. URL: http://www.wipo.int/ wipolex/en/text.jsp?file_id=235955 (дата обращения: 24.08.2016).

29. Конституция Республики Уганда 1995 года // Конституции стран мира [Электронный pecypc]. URL: http://www.uznal. org/constitution.php?text=Uganda\&language=e (дата обращения: 15.08.2016). 
30. Конституция Республики Филиппины 1987 года (Constitution of the Republic of the Philippines) // WIPO Lex [Электронный pecypc]. URL: http://www.wipo.int/wipolex/en/details.jsp?id=3451 (дата обращения: 24.08.2016).

31. Конституция Республики Хорватия 1990 года // Конституции стран мира [Электронный pecypc]. URL: http://www. concourt.am/armenian/legal_resources/world_constitutions/constit/croatia/croati-r.htm (дата обращения: 15.08.2016).

32. Конституция Российской Федерации (принята всенародным голосованием 12.12.1993) // Российская газета. - № 7. 21.01.2009.

33. Конституция Румынии 1991 года // Конституции стран мира [Электронный ресурc]. URL: http://www.concourt.am/ armenian/legal_resources/world_constitutions/constit/romania/romani-r.htm (дата обращения: 15.08.2016).

34. Конституция Словацкой Республики 1992 года // WIPO Lex [Электронный pecypc]. URL: http://www.wipo.int/wipolex/ ru/text.jsp?file_id=370874 (дата обращения: 24.08.2016).

35. Конституция Социалистической Республики Вьетнам 1992 года [Электронный pecypc]. URL: http://vietnamnews.vn/ politics-laws/250222/the-constitution-of-the-socialist-republic-of-viet-nam.html\#VoGSgsTzQ6HKbhgO.97 (дата обращения: 24.08.2016).

36. Конституция США // Конституции стран мира [Электронный ресурc]. URL: http://www.concourt.am/armenian/ legal_resources/world_constitutions/constit/usa/usa----r.htm (дата обращения: 24.08.2016).

37. Конституция Турецкой Республики 1982 г. (Constitution of the Republic of Turkey) // WIPO Lex [Электронный ресурс]. URL: http://www.wipo.int/wipolex/en/text.jsp?file_id=189924 (дата обращения: 24.08.2016).

38. Конституция Туркменистана 2008 года // WIPO Lex [Электронный pecypc]. URL: http://www.wipo.int/wipolex/en/text. jsp?file_id=248803 (дата обращения: 24.08.2016).

39. Конституция Украины 1996 года [Электронный ресурс]. URL: http://rada.gov.ua/uploads/documents/27396.pdf (дата обращения: 15.08.2016)

40. Конституция Филиппин 1987 года // Конституции стран мира [Электронный ресурc]. URL: http:/www.concourt.am/ armenian/legal_resources/world_constitutions/constit/philipin/philip-e.htm (дата обращения: 15.08.2016).

41. Конституция Финляндии 1999 года [Электронный ресурc]. URL: http://www.finlex.fi/fi/laki/kaannokset/1999/ru19990731. pdf (дата обращения: 24.08.2016).

42. Конституция Эфиопии 1994 года // WIPO Lex [Электронный pecypc]. URL: http://www.wipo.int/wipolex/en/text. jsp?file_id=193667 (дата обращения: 24.08.2016).

43. Конституция Японии 1946 года // WIPO Lex [Электронный ресурc]. URL: http://www.wipo.int/wipolex/en/text.jsp?file_ id=191550 (дата обращения: 24.08.2016).

44. Основной закон (конституция) Федеративной Республики Германия 1949 года // Конституции стран мира [Электронный pecypc]. URL: http://www.concourt.am/armenian/legal_resources/world_constitutions/constit/germany/german-r.htm (дата обращения: 15.08.2016).

45. Союзная конституция Швейцарской Конфедерации 1999 года // WIPO Lex [Электронный pecypc]. URL: http://www. wipo.int/wipolex/en/text.jsp?file_id=342835 (дата обращения: 24.08.2016).

46. Амерханов С.А. Право на развитие и проблемы его реализации (международно-правовые аспекты). Дис. ... канд. юрид. наук: 12.00.10. М., 1997. 163 с.

47. Ахметшин Р.И. К проблеме третьего поколения прав человека (международно-правовые аспекты). Дис. ... канд. юрид. наук: 12.00.10. М., 1999. 187 с.

48. Варламова Н.В. Третье поколение прав человека как форма юридизации отношений между социальными общностями // История государства и права. 2009. № 14-16. С. 46-48, 44-47, 41-45.

49. Задорин М. Ю. Конституционное право коренных малочисленных народов на развитие. Дис. ... канд. юрид. наук: 12.00.02. М., 2015. $203 \mathrm{c}$.

50. Золотухин С.В. К вопросу об эволюции концепции права на развитие // Рос. ежегодн. межд. права. 1992. СПб.: Россия - Нева, 1994. С. 164-174.

51. Золотухин С.В. К вопросу о концепции «третьего поколения прав человека» или «прав солидарности» // Сов. ежегодник межд. права. 1989-90-91. СПб.: Россия-Нева, 1992. С. 181-185.

52. Капустин А.Я. Право развития - понятие и особенности (на примере латиноамериканской международно-правовой доктрины) // А. Я. Капустин // Международное право в практике освободившихся стран: Сб. науч. трудов. М.: Изд-во УДН. 1988. С. 38-48.

53. Копылов М.Н. Право на развитие и экологическая безопасность развивающихся стран (международно-правовые вопросы). М.: Экон, 2000. 388 с.

54. Лучин В.О., Пряхина Т.М. Право на достойную жизнь и свободное развитие // Вестник юрид. фак-та. Научный журнал. М.: РГСУ, 2008. № 2. - С. 70-83.

55. Маслова С.В. Принцип права на развитие в современном международном праве. Дис. ... канд. юрид. наук: 12.00 .10 . СПб., 2003. 201 c.

56. Муравьев А. М. Право на развитие как явление правовых систем: теоретико-правовой анализ. Дис. ... канд. юрид. наук: 12.00.01. М., 2012. 208 с.

57. Николайко И.В. Становление права на развитие в современном международном праве (теоретические и практические вопросы) // Советский ежегодник международного права. 1987. М.: Наука, 1988. С. 121-133.

58. Права и свободы народов в современных источниках международного права: Сборник документов. Сост. Тузмухамедов Р.А. Казань: Кн. дом, 1995. 231 с.

59. Пряхина Т.М. Право на развитие - гарантия достойной жизни // Россия. Конституция. Достойная жизнь. Материалы научной конференции. М.: Изд-во Моск. гуманит. ун-та, 2006. С. 88-93. 
DOI: $10.7256 / 1811-9018.2016 .9 .20282$

При цитировании этой статьи сноска на dоі обязательна

Человек и государство

60. Пряхина Т.М. Право на развитие: конституционный аспект // Конституционные чтения. Межвузовский сборник научных трудов. Вып. 5. Саратов: Изд-во Поволж. акад. гос. службы, 2004. С. 7-9.

61. Тузмухамедов Р.А. «Третье поколение прав человека» и права народов // Советское государство и право. М.: Наука, 1986. № 11. С. 106-113.

62. Энтин М.Л. Международное право развития: проблемы формирования и реализации (Обзор литературы) // Сов. гос. и право. М.: Наука, 1985. № 2. С. 139-144.

63. Implementing the Right to Development. The Role of International Law. / Ed. by Stephen P. Marks. Friedrich-Ebert-Stiftung, Geneva. 2008. 149 p.

64. Iqbal, Khurshid. The Right to Development in International Law: the Case of Pakistan. Routledge, 2009. 296 p.

65. M'Baye, Keba. Le droit au development comme un droit de l'homme // Revue des droit de l'homme. 1972. Vol. V. P. 528-530.

66. Reflections on the Right to evelopment / Ed. by Arjun Sengupta, Archna Negi, Moushumi Basu. New Delhi: Sage Publications, 2005. $366 \mathrm{p}$.

\section{References (transliterated):}

1. Amerkhanov S.A. Pravo na razvitie i problemy ego realizatsii (mezhdunarodno-pravovye aspekty). Dis. ... kand. yurid. nauk: 12.00.10. M., 1997. $163 \mathrm{~s}$

2. Akhmetshin R.I. K probleme tret'ego pokoleniya prav cheloveka (mezhdunarodno-pravovye aspekty). Dis. ... kand. yurid. nauk: 12.00.10. M., 1999. $187 \mathrm{~s}$.

3. Varlamova N.V. Tret'e pokolenie prav cheloveka kak forma yuridizatsii otnoshenii mezhdu sotsial'nymi obshchnostyami // Istoriya gosudarstva i prava. 2009. № 14-16. S. 46-48, 44-47, 41-45.

4. Zadorin M. Yu. Konstitutsionnoe pravo korennykh malochislennykh narodov na razvitie. Dis. ... kand. yurid. nauk: 12.00 .02 . M., 2015. 203 s.

5. Zolotukhin S.V. K voprosu ob evolyutsii kontseptsii prava na razvitie // Ros. ezhegodn. mezhd. prava. 1992. SPb.: Rossiya Neva, 1994. S. 164-174.

6. Zolotukhin S.V. K voprosu o kontseptsii «tret'ego pokoleniya prav cheloveka» ili «prav solidarnosti» // Sov. ezhegodnik mezhd. prava. 1989-90-91. SPb.: Rossiya-Neva, 1992. S. 181-185.

7. Kapustin A.Ya. Pravo razvitiya - ponyatie i osobennosti (na primere latinoamerikanskoi mezhdunarodno-pravovoi doktriny) // A. Ya. Kapustin // Mezhdunarodnoe pravo v praktike osvobodivshikhsya stran: Sb. nauch. trudov. M.: Izd-vo UDN. 1988. S. 38-48.

8. Kopylov M.N. Pravo na razvitie i ekologicheskaya bezopasnost' razvivayushchikhsya stran (mezhdunarodno-pravovye voprosy). M.: Ekon, 2000. $388 \mathrm{~s}$.

9. Luchin V.O., Pryakhina T.M. Pravo na dostoinuyu zhizn' i svobodnoe razvitie // Vestnik yurid. fak-ta. Nauchnyi zhurnal. M.: RGSU, 2008. № 2. - S. 70-83.

10. Maslova S.V. Printsip prava na razvitie v sovremennom mezhdunarodnom prave. Dis. ... kand. yurid. nauk: 12.00 .10 . SPb., 2003. $201 \mathrm{~s}$.

11. Murav'ev A. M. Pravo na razvitie kak yavlenie pravovykh sistem: teoretiko-pravovoi analiz. Dis. ... kand. yurid. nauk: 12.00.01. M., 2012. $208 \mathrm{~s}$.

12. Nikolaiko I.V. Stanovlenie prava na razvitie v sovremennom mezhdunarodnom prave (teoreticheskie i prakticheskie voprosy) // Sovetskii ezhegodnik mezhdunarodnogo prava. 1987. M.: Nauka, 1988. S. 121-133.

13. Pryakhina T.M. Pravo na razvitie - garantiya dostoinoi zhizni // Rossiya. Konstitutsiya. Dostoinaya zhizn'. Materialy nauchnoi konferentsii. M.: Izd-vo Mosk. gumanit. un-ta, 2006. S. 88-93.

14. Pryakhina T.M. Pravo na razvitie: konstitutsionnyi aspekt // Konstitutsionnye chteniya. Mezhvuzovskii sbornik nauchnykh trudov. Vyp. 5. Saratov: Izd-vo Povolzh. akad. gos. sluzhby, 2004. S. 7-9.

15. Tuzmukhamedov R.A. «Tret'e pokolenie prav cheloveka» i prava narodov // Sovetskoe gosudarstvo i pravo. M.: Nauka, 1986. № 11. S. 106-113.

16. Entin M.L. Mezhdunarodnoe pravo razvitiya: problemy formirovaniya i realizatsii (Obzor literatury) // Sov. gos. i pravo. M.: Nauka, 1985. № 2. S. 139-144.

17. Iqbal, Khurshid. The Right to Development in International Law: the Case of Pakistan. Routledge, 2009. 296 p.

18. M'Baye, Keba. Le droit au development comme un droit de l'homme // Revue des droit de l'homme. 1972. Vol. V. P. 528-530. 